James M. Leonhardt

(PhD, University of CaliforniaIrvine) is an Assistant Professor of Marketing at the College of Business at New Mexico State University. His research is in consumer information processing and social media marketing. He also teaches Consumer Behaviour and Internet and Social Media Marketing.
Keywords: social media marketing, Affordable Care Act, health care, public policy

\section{Health care reform}

Millennials lack health insurance
James M. Leonhardt Department of Marketing, New Mexico State University, MSC 5280, PO Box 30001, Las Cruces, NM 88003-8001, USA Tel: +1 (575) 646 3486 E-mail: jleonhar@nmsu.edu

\section{Case Study}

\section{Tweets, hashtags and virality: Marketing the Affordable Care Act in social media}

\author{
James M. Leonhardt \\ Received (in revised form): 29th January 2015
}

\begin{abstract}
To help offset the costs brought on by insuring previously uninsurable consumers, the Affordable Care Act (ACA) needed adequate enrolments of millennials. To engage with this tech-savvy cohort, the Obama administration had to think outside traditional media and build a robust presence in social media. The present article provides a historical account of how the ACA was promoted to millennials using social media. In turn, it provides an example of how social media platforms, including Twitter, Facebook and YouTube, and strategies, including hashtag and virality campaigns, can be used to promote public policy adoption. Journal of Direct, Data and Digital Marketing Practice (2015) 16, 172-180. doi:10.1057/dddmp.2015.4
\end{abstract}

\section{Context}

The Affordable Care Act (ACA) made a number of changes to existing insurance industry regulations. It ended lifetime limits on health insurance coverage, restricted how insurance providers can spend policy premiums and, perhaps most notably, required insurance providers to cover preexisting conditions. Offering health care to consumers regardless of age, physical health or other mitigating factors, previously used to deny or limit coverage, helped to ensure the possibility of coverage for all US citizens.

However, to help offset the costs brought on by insuring previously 'uninsurable' consumers who, on average, required more health services, the ACA needed adequate enrolments of millennials. ${ }^{1}$ Data from the 2010 Census indicated that 48.4 million, or 18 per cent of the US population, lacked sufficient health insurance coverage. Of this group, 20.1 million, or 41.5 per cent, were between the ages of 18 and $34 .^{2}$ This age group, referred to as the millennial generation, often lack sufficient health insurance coverage because, relative to older generations such as the Baby Boomers, they are, on average, less affluent and require health services less frequently. 3,4

To help ensure the sustainability of the ACA, a marketing plan was needed to encourage millennials to sign up for health insurance through Healthcare. gov. ${ }^{5}$ To engage with this tech-savvy cohort, marketers of the ACA, namely, the Obama administration, had to think outside traditional media channels 


\section{Targeting millennials}

\section{Entering social media via Twitter}

\section{The ACA on Facebook and Google+}

\section{Sharing web video on YouTube}

such as television, radio and print and develop a robust presence in social media. Compared with other generations, such as Generation X and the Baby Boomers, millennials are the most engaged in social media, spending an average of 8 hours a week in social media. ${ }^{6,7}$ In addition, millennials are more likely than older generations to have built their own community networks within social media platforms and many rely on these networks as their primary source for news and entertainment. ${ }^{8,9}$

\section{Creating a presence in social media}

The Obama administration had previously used social media to engage with millennials during its 2008 and 2012 election campaigns, and this likely contributed to its victories against Senator John McCain and Former Governor Mitt Romney, who both had much smaller social media footprints. ${ }^{10,11}$ Perhaps, drawing on this experience, during President Obama's first term, the administration began laying the groundwork for the ACA's presence in social media. As early as November of 2009, the ACA got its own Twitter account, using the handle @ HealthCareGov, which functioned as a Twitter username. However, it did not begin tweeting until 1 July 2010. This was to promote the newly redesigned website Healthcare.gov. Twitter was established in 2006 and is a popular microblogging service. It combines the services of a social media platform with those of SMS text messaging, allowing users to create 'tweets' that are 140 characters or less. In addition, Twitter allows users to create and promote user-generated content by 'tweeting', 'retweeting', 'favourite-ing' and ‘@-mentioning'.

On 23 March 2010, President Obama signed the ACA into law. ${ }^{12}$ That same day, official Facebook and Google+ pages were created for Healthcare.gov to promote the ACA. Facebook, developed and launched in 2004, has grown to be the largest and most active social media networking platform in the world. While originally intended for university students, the platform eventually allowed anyone over the age of 13 to create a personal profile and interact with 'friends'. Google+ was launched in 2011 and allows users to compartmentalize their friend groups into 'circles', while also simplifying privacy features to help users manage what they share and with whom. Both platforms use similar functions for interactive content between users, with Facebook using 'likes' and 'shares' and Google+ using ' +1 ' and 're-share'. Both platforms have a large activeuser base. As of December 2013, Facebook had about 693 million active users, while Google+ had about 343 million. ${ }^{13,14}$

In early 2011, as the 2012 election cycle went into full swing, an official Healthcare.gov YouTube channel was created and more than a dozen videos were uploaded in its first 2 weeks. YouTube, a subsidiary of Google Inc, is a video-sharing platform in which users can upload video content, be it original or otherwise, so long as the content complies with fair use law. ${ }^{15}$ In addition, 'YouTubers' can set up their own channel, upload videos and create playlists to be viewed by their subscribers and the general public. In the case of Healthcare.gov's YouTube channel, HealthCareGov, the earliest uploaded videos appeared as a series in which 


\section{Healthcare.gov goes live}

Technical setbacks and low enrolment

\section{Return to traditional media}

\section{Hashtag campaigns \#GetCovered and \#Cubiertos}

each video appealed to, respectively, young adults, people with disabilities, families with children, large businesses, pregnant women, small businesses and senior citizens. While early videos focused on getting the American public behind the ACA, later videos served as educational tutorials on health insurance literacy and navigating the new health insurance regulations.

\section{The insurance marketplace: Healthcare.gov}

Soon after Obama's re-election in 2012, his administration went to work on implementing the ACA and launching a health insurance marketplace on Healthcare.gov. The marketplace is an online platform on Healthcare. gov through which consumers can shop for health insurance coverage and learn more about their health insurance options. In addition, by creating a 'share your story' feature on Healthcare.gov, consumers were given the opportunity to communicate with one another and share their experiences with other consumers visiting the marketplace. On 1 October 2013, Healthcare.gov and the marketplace went live. Fourteen states and the District of Columbia chose to operate their own marketplaces, while an additional ten states opted to run joint state-federal marketplaces.

The remaining 26 states declined to create their own marketplaces and consumers in those states were directed to the primary, federally operated Healthcare.gov website. ${ }^{16}$

As was widely noted in the media, the federal website suffered significant technical setbacks in its first month. The administration blamed these technical difficulties on overwhelming web traffic. In addition, to shop for health insurance policies, consumers were required to create an online account, a process that not only involved multiple systems and servers but also, if just one system or server stumbled, could bottleneck the entire system. ${ }^{17,18,19}$ Largely as a result of these setbacks, by mid-

November of 2013, only 26,000 people had signed up for health insurance through Healthcare.gov. This number was far below the administration's expectations - even though about 106,000 had completed the enrolment process up to the crucial step of actually purchasing a health-care plan. ${ }^{20,21}$

\section{Increasing enrolments before the deadline}

The administration needed to overcome these low enrolments and restore the public's faith in the ACA. In turn, the administration and the state-run exchanges increased their reliance on traditional media and, in the 5 weeks following Healthcare.gov's uneasy launch, state-run exchanges and the federal government collectively spent US\$194 m on television, radio and internet advertisements. This level of spending was significantly high compared with the $\$ 216 \mathrm{~m}$ spent in all of 2012 . $^{22}$ In addition, the administration renewed its focus on social media with the implementation of hashtag and virality campaigns.

In January of 2014, with less than 3 full months left in the open enrolment period, enrolment numbers were still below expectations. ${ }^{21}$ To help increase enrolments, especially among millennials and 


\section{Magic Johnson and Alonzo Mourning on YouTube}

\section{Results of the hashtag campaign}

\section{Virality campaign}

\section{Galifianakis interviews President Obama on FunnyorDie.com}

Spanish-speaking citizens, the administration initiated a hashtag campaign, popularizing the Twitter hashtags \#GetCovered and \#Cubiertos.

A hashtag, much like an @-mention, helps to make online content more searchable, similar to 'tags' or 'keywords' used by news websites and blogs. To help promote these hashtags, the administration enlisted the help of numerous celebrities, including Hall of Fame basketball players Magic Johnson and Alonzo Mourning.

In Magic Johnson's 30-second YouTube video, he implored consumers to visit Healthcare.gov and compare prices and plans under the ACA. He ended his endorsement on a lighthearted, yet serious note: 'It might sound like "magic", but it's real. Protect your health. Enroll today'. Alonzo Mourning's YouTube video similarly appealed to the public to enrol for health insurance coverage through Healthcare.gov. Mourning used his personal story of discovering he suffered from a life-threatening kidney disease at the height of his basketball career. He acknowledged that he was lucky to be insured and urged viewers to 'Enrol today ... so you can stay in the game'.

After its launch, \#GetCovered was tweeted an average of 100 times daily and was viewed by about 750,000 Twitter users. ${ }^{23}$ Considering that, as of 2010, only 4 per cent of Twitter users used Spanish on the site, \#Cubiertos was not nearly as prolific, although it was tweeted an average of 20 times daily and was viewed by about 13,500 Twitter users. $^{24}$ The hashtag campaign also likely helped to increase Healthcare.gov's number of followers on Twitter and its number of views on YouTube. For example, from January to February 2014, Healthcare.gov added about 5,000 new followers on Twitter and its total number of followers was about 154,000 . In addition, within the same period, the most popular YouTube video, 'Get covered in the health insurance marketplace', went from 18,000 to more than 500,000 total views.

\section{A final push to increase enrolments}

Despite the increasing popularity of Healthcare.gov in social media, 1 month before the 31 March close of open enrolment, enrolment numbers in the marketplace were still much lower than expected. ${ }^{3,21}$ Most importantly, millennials' enrolment numbers were still extremely low. Of the 7 million people projected to sign up for health care through Healthcare.gov, at least 2.7 million millennials (about 40 per cent of the total) were needed to make the ACA sustainable. However, by early March, only a quarter of all enrolees were between the ages of 18 and 34 . To get more millennials to enrol before the enrolment deadline, the administration needed to reach millions of millennials as quickly as possible. A marketing strategy that leveraged the power of virality was perhaps the best option.

On 11 March 2014, less than 3 weeks from the close of open enrolment on Healthcare.gov, the administration facilitated the release of online video content that they hoped would go viral. ${ }^{25}$ The content was an episode of the web series Between Two Ferns with Zach Galifianakis, in which 
The interview goes viral

\section{Newspaper and TV pick up on the interview}

President Obama was 'interviewed'. The web series appeared on the comedy website FunnyorDie.com. Galifianakis, a comedian and actor, has hosted the show since 2008. The shows are marked by Galifianakis' offbeat humour that often results in his guests seeming visibly uncomfortable. The show with Galifianakis and President Obama included an exchange of jokes and mild insults. At one point Galifianakis interrupts the President and says, 'Okay, let's get this over with ... What did you come here to plug?' In line with Galifianakis' comedic tone, the President replies that he only came on the show because he had 'something to plug'. The President then encourages 'young Americans' (including Galifianakis, who complains of spider bites) to get health insurance through Healthcare.gov.

To promote the video's release, FunnyorDie.com tweeted a link to the video. This tweet received about 2,500 retweets and 1,400 'favourites' in just a few hours. In addition, White House senior communications advisor Tara McGuinness used Twitter to promote the video, as did Healthcare.gov's official Twitter account. Even President Obama took to the official White House Twitter account to thank Galifianakis for his part in promoting Healthcare.gov (these tweets are shown in Figures 1 and 2).

In addition, within the day (11 March 2014) major newspapers, such as The Wall Street Journal, The Huffington Post and The New York Times, responded to the interview with short articles on their websites. By day's end, the interview was being discussed on national television news networks including Fox and CNN. By the next morning, it had become a trending topic on Facebook and garnered several small articles in major national newspapers.

\section{Results of the campaign}

The average Between Two Ferns episode garnered roughly 6 million views, but during its first day online, the episode with President Obama had 8 million views. Within a week following the interview's release, it had been viewed over 22 million times on FunnyorDie.com, reaching 'immortal' status - the website's designation for videos that receive

Tara McGuinness

@HealthCareTara

\section{FunnyorDie.com is the \#1 source of referrals to HealthCare.gov right now.}

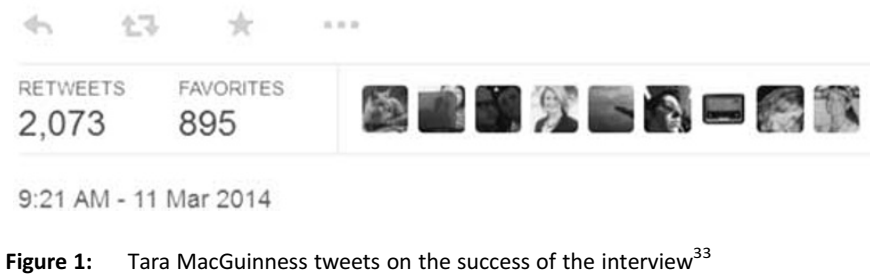




\section{Hey@galifianakisz, thanks for sending so many folks to \#GetCoveredNow at Healthcare.gov. And good luck with those spider bites. -bo}

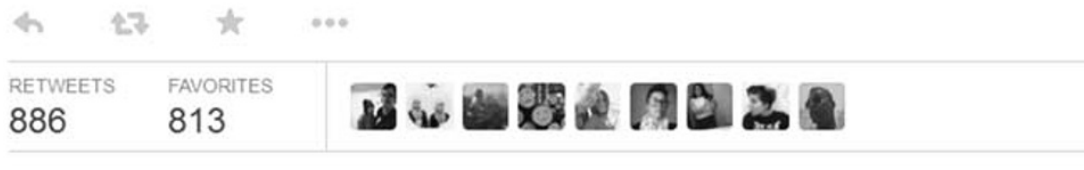

12:16 PM - 11 Mar 2014

Figure 2: President Obama tweets a thank you to Galifianakis ${ }^{34}$

overwhelmingly positive reviews. In addition, on the day of the video's release, Healthcare.gov reportedly experienced a 40 per cent spike in traffic, with FunnyorDie.com largely credited for its direct-link referrals. Moreover, in the 24 hours following the video's release, Healthcare.gov's official Twitter account gained almost a thousand new followers and President Obama gained 35,000 new Twitter followers. In addition, consumer sentiment towards the President's interview on Between Two Ferns was generally positive. For instance, on YouTube, only about 5 per cent of YouTube viewers rated the interview as 'thumbs-down'. And on FunnyorDie.com, only about 15 per cent of viewers designated the episode as 'Die', the comedy website's parlance for a negative review.

Pros and cons of virality

\section{Social media zones}

The administration's virality campaign created a level of brand awareness for the ACA that might not have been possible without the use of social media, at least at this rate and cost. As a comparison, the average cost of a 30 -second primetime television advertisement in 2014 was $\$ 112,100$ and print advertisements can cost $\$ 3,000$ to more than $\$ 28,000$, depending on the publication and the size of the advertisement. ${ }^{26,27}$ On the other hand, such a comparison fails to account for the inherent unpredictability of virality. ${ }^{28}$ While it may be the case that the interview between President Obama and Galifianakis reached millions of viewers, this was not typical of the videos used to promote the ACA in social media. For instance, consider the variability in Healthcare.gov's most and least viewed YouTube videos. Healthcare.gov's most popular video, 'Get covered in the health insurance marketplace', was viewed more than 2.3 million times in less than a year, while its least popular video, 'Improving Medicare in 2011: Bonus payments for primary care', received only 192 views in 3 years online.

\section{Limitations in the administration's social media strategy}

In hindsight, it is debatable whether the administration could have done better in promoting the ACA in social media. For instance, might it have reached its enrolment needs if it had worked to create a presence in all areas of social media? According to some marketing strategists, a complete 


\section{Social community, publishing and commerce}

\section{No presence in social entertainment}

\section{Targeting Spanish- speaking millennials}

\section{Social media in future public policies}

social media marketing strategy should create and maintain consumer engagement across the so-called 'zones' of social media, categorized as social community, social publishing, social commerce and social entertainment. $^{29}$

On the basis of this categorization, we can observe that the ACA had a presence in the social community zone through its Facebook and Google+ accounts. It had a large presence in the social publishing zone with the Twitter accounts and YouTube channel. In addition, by creating a 'share your story' feature on Healthcare.gov, the administration pushed Healthcare.gov into the social commerce zone by giving consumers the opportunity to communicate with one another and share their experiences with the health-care marketplace.

Notably, the ACA did not have a presence in the social entertainment zone, which includes brand placement in social media games or the creation of a new game, an 'advergame', for the purpose of advertising a brand. In not entering this zone, it may have missed an opportunity to engage with social-game-loving millennials. ${ }^{30}$ Similar to other advergames, such as Post Food's 'Postopia' or Old Spice's 'Dikembe Motumbo's 41/2 Days to Save the World', an online gaming platform could have been created to promote the ACA. In addition, the administration could have capitalized on the popularity of interactive online games, such as Angry Birds, Words with Friends or Bejeweled, by embedding advertisements into the game play, as is most often seen with the free versions of the applications. The zone in which it had the most success is debatable - however, it had much success in the social publishing zone. Both the hashtag campaign and the virality campaign heavily utilized this zone and these two campaigns seemed successful in generating last-minute referrals to Healthcare.gov.

Furthermore, perhaps more could have been done to reach Spanishspeaking millennials. Spanish is the most spoken non-English language used in the United States, with about 38 million people speaking Spanish in their homes. ${ }^{31}$ The administration attempted to reach Spanish speakers through Twitter with \#Cubiertos and by launching a Spanish-language Marketplace, CuidadoDeSalud.gov. However, despite this apparent commitment to reaching the Spanish-speaking community, only 15 of Healthcare.gov's 134 YouTube videos were in Spanish. In addition, it did not utilize Spanish-speaking celebrities in the same way that it enlisted Magic Johnson and Alonzo Mourning. In addition, although Healthcare. gov listed non-English-language resources on its website, it offered no direct links to CuidadoDeSalud.gov and only offered PDF reference documents in other non-English languages, such as Chinese, Korean, Portuguese, Vietnamese, French Creole, Polish and five others.

\section{Conclusion}

Despite these limitations, there is no doubt that social media played a key role in promoting the ACA to millennials. As a result, this case will likely serve to inform the marketing of future public policies in social media. In particular, from this case it is apparent that effective social media marketing requires an active presence across multiple social media 
platforms. As discussed, the ACA had an active presence on Twitter, Facebook, Google+ and YouTube. By maintaining this multiple presence, the administration was then better able to support its subsequent hashtag and virality campaigns. In turn, these campaigns generated greater awareness for the ACA across both traditional and social media. More generally, this increase in consumer awareness may have contributed to the recent decrease in uninsured Americans. ${ }^{32}$ The Congressional Budget Office predicts this trend to continue and estimates 19 million enrolments by 2015 and 25 million by $2016 .{ }^{32}$ However, whether this is the case may depend on the extent to which the ACA continues to be promoted in social media.

\section{References}

1. Schultz, E.J. (2013) 'How to sell health insurance in the era of Obamacare', Ad Age. Retrieved from http://adage.com/article/cmo-strategy/sell-health-insurance-era-obamacare/244969/.

2. Office of Communications, Centers for Medicare and Medicaid Services. (2013) Audience segmentation for the emerging health insurance marketplace. U.S. Department of Health and Human Services, January. Retrieved from http://capsules.kaiserhealthnews.org/wp-content/ uploads/2013/03/social-marketing-research-for-the-health-insurance-marketplace.pdf.

3. Kliff, S. (2013) 'Obamacare needs young people to sign up. And it looks like they're starting', The Washington Post, 11 October. Retrieved from http://www.washingtonpost.com/blogs/wonkblog/ wp/2013/10/11/obamacare-needs-young-people-to-sign-up-and-it-looks-like-theyre-starting/.

4. Betz, J. (2013) 'I don't need health care: Millennials threaten success of reform', Aljazeera America. World Wide Web, http://america.aljazeera.com/articles/2013/9/30/-i-dona-t-needhealthcaremillennialsmaythreatensuccessofreform.html, accessed 15 October 2014.

5. Levitt, L. (2013) 'Why Obamacare needs millennials', News@ JAMA. World Wide Web, http:// newsatjama.jama.com/2013/07/24/jama-forum-why-obamacare-needs-millennials/, accessed 15 October 2014.

6. Marketing Charts. (2013) Millennials up their time online. Marketing Charts, 21 January, http://www.marketingcharts.com/wp/online/millennials-up-their-time-online-26405/, accessed 28 May 2014.

7. Lachman, M. and Brett, D. (2013) Generation Y: Shopping and entertainment in the digital age. Urban Land Institute. World Wide Web, http://www.uli.org/wp-content/uploads/ULI-Documents/ Generation-Y-Shopping-and-Entertainment-in-the-Digital-Age.pdf, accessed 19 February 2015.

8. Madden, M., Lenhart, A., Duggan, M., Cortesi, S. and Gasser, U. (2013) Teens and technology 2013, Pew Research Internet Project. World Wide Web, http://www.pewinternet.org/2013/03/13/ main-findings-5/, accessed 28 May 2014.

9. Pew Research Center. (2014) Millennials in adulthood. In 'The Next America'. Pew Research: Social \& Demographic Trends, 7 March. Retrieved from http://www.pewsocialtrends.org/2014/ 03/07/millennials-in-adulthood/.

10. Harfoush, R. (2009) Yes we did! An Inside Look at How Social Media Built the Obama Brand, Pearson, San Francisco.

11. Beaujon, Andrew. (2012) Study: Obama campaign uses online media far better than Romney. Project for Excellence in Journalism. The Poynter Institute, 15 August. Retrieved from http:// www.poynter.org/latest-news/mediawire/185033/study-obama-campaign-uses-online-mediafar-better-than-romney/.

12. Stolberg, S. G. and Pear, R. (2010) 'Obama signs health care overhaul bill, with a flourish', The New York Times, 23 March. Retrieved from http://www.nytimes.com/2010/03/24/health/policy/ 24health.html?_r=0.

13. Petri, A. (2011) 'Grow up! Google+ isn't the new Facebook. It's the anti-Facebook', The Washington Post, 29 June. Retrieved from http://www.washingtonpost.com/blogs/compost/post/ grow-up-google-plus-isnt-the-new-facebook-its-the-anti-facebook/2011/06/29/AGR7csqH_ blog.html. 
14. Kosner, A. W. (2013) 'Watch out Facebook, with Google+ at \#2 and YouTube at \#3, Google Inc. could catch up', Forbes, 26 January. Retrieved from http://www.forbes.com/sites/anthonykosner/ 2013/01/26/watch-out-facebook-with-google-at-2-and-youtube-at-3-google-inc-could-catch-up/.

15. Sorkin, A. R. and Peters, J. W. (2006) 'Google to acquire YouTube for $\$ 1.65$ billion', The New York Times, 9 October. Retrieved from http://www.nytimes.com/2006/10/09/business/ 09cnd-deal.html?pagewanted=print.

16. Burch, M. and Ketineni, L. (2013) 'Find your state's healthcare exchange', The Wall Street Journal, 21 October. Retrieved from http://online.wsj.com/news/articles/SB10001424052702 304526204579099422440044100.

17. Weisman, J. and Peters, J. W. (2013) 'US shutdown nears as House votes to delay health law', The New York Times, 28 September. Retrieved from http://www.nytimes.com/2013/09/29/us/ politics/budget-talks-government-shutdown.html?pagewanted=all.

18. Weaver, C. and Radnofsky, L. (2013) 'Healthcare.gov's flaws found, fixes eyed', The Wall Street Journal, 10 October. Retrieved from http://online.wsj.com/news/articles/SB100014240527023 04500404579127783931191264.

19. Lahm, R. J. (2013) 'Obamacare and small business: Delays and 'glitches' exacerbate uncertainty and economic consequences', Journal of Management and Marketing Research, Vol. 16, August, pp. 1-16.

20. Arkin, D. (2014) '22 pens, 47 million Americans: Obamacare by the numbers', NBC News, 1 April. Retrieved from http://www.nbcnews.com/storyline/obamacare-deadline/22-pens-47million-americans-obamacare-numbers-n68271.

21. Larotonda, M. (2014) 'Obamacare enrollment over 4 million, still missing critical Millennials', ABC News, 11 March. Retrieved from http://abcnews.go.com/blogs/politics/2014/03/obama care-enrollment-over-4-million-still-missing-critical-millennials/.

22. Martin, T. W. (2013) 'Health insurers crank up ad spending', The Wall Street Journal, 15 December. Retrieved from http://online.wsj.com/news/articles/SB10001424052702303722 104579238432305175584.

23. Hashtracking. (2014) Powerful Tracking for Hashtags: \#Cubiertos, Hashtracking Inc. World Wide Web, https://www.hashtracking.com/explorer/?hashtag=Cubiertos.

24. Hashtracking. (2014) Powerful Tracking for Hashtags: \#GetCovered, Hashtracking Inc. World Wide Web, https://www.hashtracking.com/explorer/?hashtag=GetCovered.

25. Johnson, T. (2014) 'How Funny or Die got President Obama on Zach Galifianakis' "Between Two Ferns" ', Variety, 11 March. Retrieved from http://variety.com/2014/digital/news/presidentobama-on-zach-galifianakis-between-two-ferns-watch-1201129329/.

26. TV Cost \& CPM trends: Network TV primetime (M-Su). (2014) Television Bureau of Advertising, February. Retrieved from http://www.tvb.org/trends/4718/4707.

27. Becket, X. (2014) The cost of advertising nationally broken down by medium. Webpage FX, 29 April. Retrieved from http://www.webpagefx.com/blog/business-advice/the-cost-of-advertisingnationally-broken-down-by-medium/\#mag.

28. Berger, J. (2014) Contagious: Why things Catch on, Simon \& Schuster, New York.

29. Tuten, T. L. and Solomon, M. R. (2013) Social Media Marketing, Pearson Education, Upper Saddle River, NJ.

30. Zogby, J. (2014) 'Millennials and video games: Developing skills for the future', Forbes, 22 June. Retrieved from http://www.forbes.com/sites/johnzogby/2014/06/22/millennials-andvideo-games-developing-skills-for-the-future/.

31. Gonzalez-Barrera, A. and Lopez, M. H. (2013) Spanish is the most spoken non-English language in U.S. homes, even among non-Hispanics. Pew Research Center, 13 August. Retrieved from http://www.pewresearch.org/fact-tank/2013/08/13/spanish-is-the-most-spoken-non-englishlanguage-in-u-s-homes-even-among-non-hispanics/.

32. Semro, B. (2014) 'Numbers tell the story of ACA's success, but they also show millions are missing out', The Huffington Post, June. Retrieved from http://www.huffingtonpost.com/ bob-semro/numbers-tell-the-story-of-obamacare_b_5228695.html.

33. Internet Archive Wayback Machine. (2014) Twitter.com/HealthCareTara. Internet Archive, 11 March. Retrieved from http://web.archive.org/web/20140313080841/https://twitter.com/ HealthCareTara.

34. Internet Archive Wayback Machine. (2014) Twitter.com/BarackObama. Internet Archive, 11 March. Retrieved from https://web.archive.org/web/20140310050233/https://twitter.com/ BarackObama. 